\title{
Short communication: Risk of severe heel erosion increased with parity and stage of lactation in freestall-housed dairy cows
}

\author{
N. Chapinal, ${ }^{* 1}$ L. G. Baird, ${ }^{*}$ L. C. Pinheiro Machado,† M. A. G. von Keyserlingk, ${ }^{*}$ and D. M. Weary ${ }^{*}$ \\ *Animal Welfare Program, University of British Columbia, 2357 Main Mall, Vancouver BC, V6T 1Z4, Canada \\ †Lab. Etologia Aplicada—Depto. de Zootecnia e Des. Rural, Universidade Federal de Santa Catarina, Rod. Admar Gonzga, 1346, Itacorubi, \\ Florianópolis, SC, Brazil
}

\section{ABSTRACT}

Heel erosion is the most prevalent hoof lesion in housed dairy herds, particularly in freestall facilities. It is associated with hoof contact with manure slurry and abrasive floors. The objective was to assess changes in the risk of heel erosion from the dry period to mid lactation in primiparous and multiparous dairy cows. Nineteen pregnant primiparous cows, 22 late-lactation multiparous cows (parity $=3.2 \pm 1.4$; days in milk $=$ $221 \pm 38$ ), and 16 nonlactating, pregnant multiparous cows (parity $=3.7 \pm 1.4$ ) housed in a freestall barn with concrete flooring were followed until mid lactation. The hind hooves of all the cows were examined approximately every $7 \mathrm{wk}$ and heel erosion was scored. Multiparous cows more likely had heel erosion than primiparous cows (odds ratio $=11.0 ; 95 \%$ confidence interval $=3.7,32.7)$. Time relative to calving showed a significant quadratic effect, revealing that the risk of heel erosion increased more rapidly as lactation progressed. Survival analysis showed that multiparous cows had a higher relative risk of developing heel erosion than primiparous cows (hazard ratio $=3.4$ ). No cows improved between early and mid lactation, but 18 cows worsened. In conclusion, stage of lactation and parity were major risk factors for severe heel erosion in dairy cattle housed in freestalls.

Key words: lameness, hoof lesion, parity, stage of lactation

Hoof pathologies such as sole lesions, white-line separation, digital dermatitis, interdigital hyperplasia, and heel erosion are of increasing concern to the dairy industry. Pitiable hoof health can result in economic losses to dairy producers (Smit et al., 1986; Smits et al., 1992) through decreased production (Tranter and Morris, 1991; Green et al., 2002), reduced reproductive performance (Tranter and Morris, 1991), and treatment costs (Esslemont and Peeler, 1993). Moreover, some

Received December 7, 2009.

Accepted April 6, 2010.

${ }^{1}$ Corresponding author: nchapinal@yahoo.com hoof pathologies cause pain, compromising the welfare of affected cows (Whay et al., 1997).

Heel erosion is the most prevalent hoof lesion and likely the most prevalent disease in confined dairy herds, with every cow affected in some cases (Manske et al., 2002b; Capion et al., 2009). The heel is a major weight-bearing surface of the hoof and acts as a shock absorber during locomotion (Greenough and Weaver, 1997). As a result, severe heel erosion may compromise shock absorbance and alter the weight-bearing portion of the hoof, predisposing it to horn lesions. Although heel erosion does not have a clear effect on locomotion in the mild or moderate forms, Frankena et al. (2009) found a higher risk of lameness in cows with severe cases of heel erosion.

The causes of heel erosion are not clearly understood, which makes prevention difficult. Heel erosion is associated with hoof contact with manure slurry (Bergsten and Pettersson, 1992), with prevalence and severity of heel erosion typically higher in freestall facilities than in tiestalls or pasture-based systems (Bergsten and Herlin, 1996; Sogstad et al., 2005; Olmos et al., 2009). Abrasive floors (e.g., concrete) have a more detrimental effect on the heel compared with rubber or rubbered slats (Hultgren and Bergsten, 2001; Vanegas et al., 2006). Heel erosion likely shares the same causative factors as digital and interdigital dermatitis, and associations between these diseases have been reported (Manske et al., 2002b; Capion et al., 2009). Some studies have considered dermatitis and heel erosion as part of the same process (Manske et al., 2002a; Frankena et al., 2009).

Previous research on heel erosion was restricted primarily to point-in-time estimates of farm prevalence based on a single assessment (Manske et al., 2002a; Sogstad et al., 2005). Other studies (Webster, 2002; Olmos et al., 2009) analyzed changes in heel erosion severity over time by estimating an overall severity score per cow (as the sum of the scores assigned to each claw) and analyzing this as a continuous variable; this approach is problematic given that heel erosion scores are nominal and only severe heel erosion seems to impair gait. 
Little research has focused on the development of heel erosion over time, taking into consideration age of the animal. To our knowledge only 2 previous studies examined this relationship. Enevoldsen et al. (1991) reported that severity of heel erosion increased with parity, when comparing cows in fourth or greater lactation with cows in third lactation, and with stage of lactation within multiparous cows, although this finding may have been confounded with seasonal pasture access. Offer et al. (2000) analyzed severity as a continuous variable and found that severity increased in early lactation and decreased in late lactation, but these results should be viewed with caution because cows were provided access to pasture only during late lactation.

The objective was to assess changes in the risk of severe heel erosion over time by following a cohort of cows within a commercial dairy herd. The development of severe heel erosion was followed from before calving through mid lactation, separately for primiparous and multiparous cows.

The study was conducted at The University of British Columbia Dairy Education and Research Centre (Agassiz, British Columbia, Canada). All animals were enrolled on June 15, 2002. At enrollment, 19 animals were pregnant primiparous, 22 were late-lactation multiparous (mean $\pm \mathrm{SD}$; parity $=3.2 \pm 1.4 ; \mathrm{DIM}=221$ \pm 38 ), and 16 were nonlactating, pregnant multiparous (parity $=3.7 \pm 1.4$ ). Animals were followed until 200 DIM of the following lactation. Cows were housed continuously indoors, dispersed among the 225-cow lactating cow herd in a freestall barn with concrete flooring and automatic alley scrapers that ran every $4 \mathrm{~h}$. The ratio of stalls to cows was 1:1. Stall design was the same for lactating and dry cows. Animals were fed diets in the form of a TMR that varied with stage of lactation based on NRC (2001). Fresh feed was provided at approximately 0600 and $1515 \mathrm{~h}$ along a concrete feed alley with $60 \mathrm{~cm}$ of feed space per animal. Ten of the primiparous, 9 of the lactating multiparous, and 6 of the dry multiparous cows were on pasture for a limited period of time (94 $\pm 40 \mathrm{~d})$ before the last $3 \mathrm{wk}$ before calving. Lactating cows on pasture were brought into the freestall barn twice daily for milking at approximately 0630 and $1530 \mathrm{~h}$ and received $15 \mathrm{~kg}$ of supplemental concentrate per cow per day such that energy and protein intakes were similar to that of the freestall-housed cows.

The hind hooves of all cows were scored approximately every $7 \mathrm{wk}(52 \pm 8 \mathrm{~d})$. Because all animals were scored on the same days, the number of times each animal was scored during each stage of lactation varied: cows were scored (mean $\pm \mathrm{SD}$ ) $2.25 \pm 0.89$ times before calving, $1.85 \pm 0.36$ times in early lactation (0 to 100 $\mathrm{DIM}$ ), and $1.19 \pm 0.40$ times in mid lactation (100 to
200 DIM). The hind heels of each cow were scored by 2 trained observers according to the criteria outlined by Smilie et al. (1999). Heel erosion was scored on a scale from 0 to 4 [ $0=$ no erosion; $1=$ shallow irregular grooves $(<0.5 \mathrm{~cm}) ; 2=$ deep irregular grooves $(>0.5$ $\mathrm{cm}) ; 3=$ shallow oblique grooves; and $4=$ deep oblique grooves, major loss of heel structure]. Throughout the study, only 4 cows had ulcers; 1 of these cows also had an abscess on the opposite hoof. These cows were correctively trimmed and a block was placed on the unaffected claw. The rest of the cows were not correctively hoof trimmed.

Following Smilie et al. (1999), heel erosion scores were dichotomized into severe (scores 3 and 4) or not severe $(<3)$. Preliminary analyses showed no differences between left and right hooves, so results are reported on a per-cow basis and cows were considered afflicted with severe heel erosion when at least 1 of the heels scored 3 or 4 . Preliminary analysis showed that the period of pasture access precalving did not affect measures of hoof health, so this factor was not considered further.

The effect of parity (primiparous vs. multiparous) on the incidence of heel erosion was tested using a generalized linear model (PROC GENMOD in SAS; SAS Institute, 2003), specifying the logit link function and binary distribution. Time relative to calving was included in the model as a repeated measure and was considered either continuous (linear and quadratic effect of day relative to calving) or categorical (3 periods: precalving, early lactation or DIM $\leq 100$, and late lactation or DIM $>100$ and $\leq 200$ ). Bonferroni's adjustment was applied for multiple comparisons. Binomial tests were performed to determine whether animals improved or worsened between observation periods. In addition, the time from the first hoof examination until severe heel erosion was first recorded was analyzed with multivariable survival analysis using Cox's proportional hazards regression (PROC PHREG). Two primiparous cows and 13 multiparous cows presented severe heel erosion at the first examination and were discarded from this analysis. Although survival analysis models time to an event, in Cox's model the output is expressed as a hazard ratio, or instantaneous relative risk of being diagnosed with a lesion over a set time interval. The output can be interpreted as the relative daily probability of being diagnosed with severe heel erosion.

Multiparous cows more likely had severe heel erosion than primiparous cows [odds ratio $(\mathbf{O R})=11.0 ; 95 \%$ $\mathrm{CI}=3.7,32.7 ; P<0.001 ;$ Figure 1$]$. Time relative to calving showed a quadratic effect $(P<0.001)$, indicating that the risk of severe heel erosion increased more rapidly as lactation progressed. Results were similar when time was categorized into 3 periods. There were no differences between the precalving period and early 


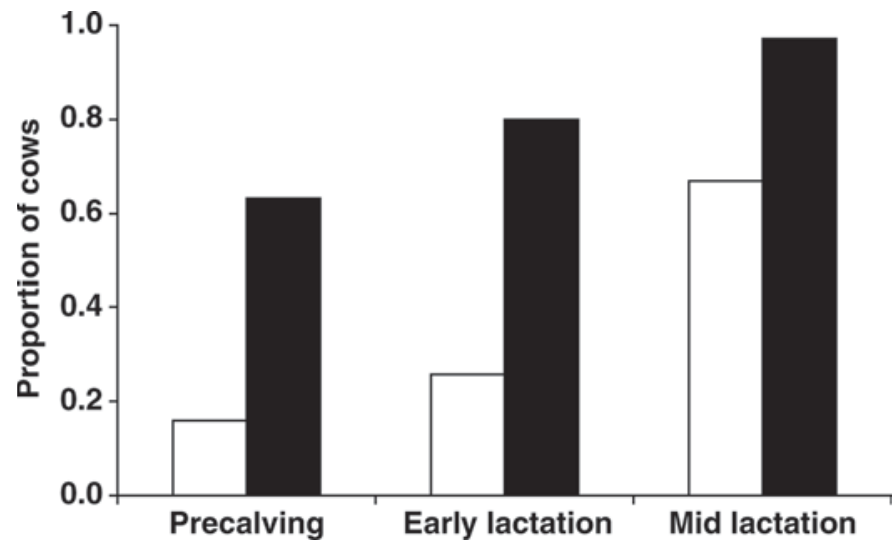

Figure 1. Proportion of primiparous (white bars) and multiparous (black bars) cows with severe heel erosion during the precalving $(-100$ to 0 DIM), early lactation (0 to 100 DIM), and mid lactation (100 to 200 DIM) observation periods.

lactation $(P=0.3)$, but cows were more likely afflicted with severe heel erosion in mid lactation than in both the precalving period $(\mathrm{OR}=15.6 ; 95 \% \mathrm{CI}=4.6,52.7$; $P>0.001)$ and in early lactation $(\mathrm{OR}=7.6 ; 95 \% \mathrm{CI}=$ $2.4,23.8 ; P=0.001)$. There was no interaction between parity and day or period in any analysis $(P>0.3$ in all cases).

The survival analysis (Figure 2) showed that multiparous cows had a higher relative daily probability of developing severe heel erosion than primiparous cows (hazard ratio $=3.4 ; P=0.001$ ). The survival analysis considers only the first time that the event (severe heel erosion) happens and therefore does not consider improvement. Heel erosion scores improved (i.e., declined from severe to not) between the precalving and early lactation periods for 4 animals, but worsened for 9 others (Binomial test: $P=0.09$ ). No cow improved between early and mid lactation, but 18 cows worsened (Binomial test: $P<0.001$ ). By the end of this study, 50 of the 57 cows had been diagnosed with severe heel erosion at least once. Six of the 7 animals that did not show severe heel erosion were primiparous.

The results show the importance of considering parity and the stage of lactation when estimating prevalence or incidence of heel erosion on farms. The prevalence of heel erosion in freestall housing reported in other studies varied from $<10 \%$ of cows affected (Cramer et al., 2008) to $100 \%$ (Capion et al., 2009). Comparisons between studies are difficult because of differences in the definition of heel erosion and differences in housing and climatic conditions. Smilie et al. (1999), using the same scoring system as in this study, evaluated 13 herds in Ohio and found that $13.3 \%$ of the heels presented severe heel erosion. They assessed primiparous and multiparous cows from $60 \mathrm{~d}$ before calving to $100 \mathrm{~d}$

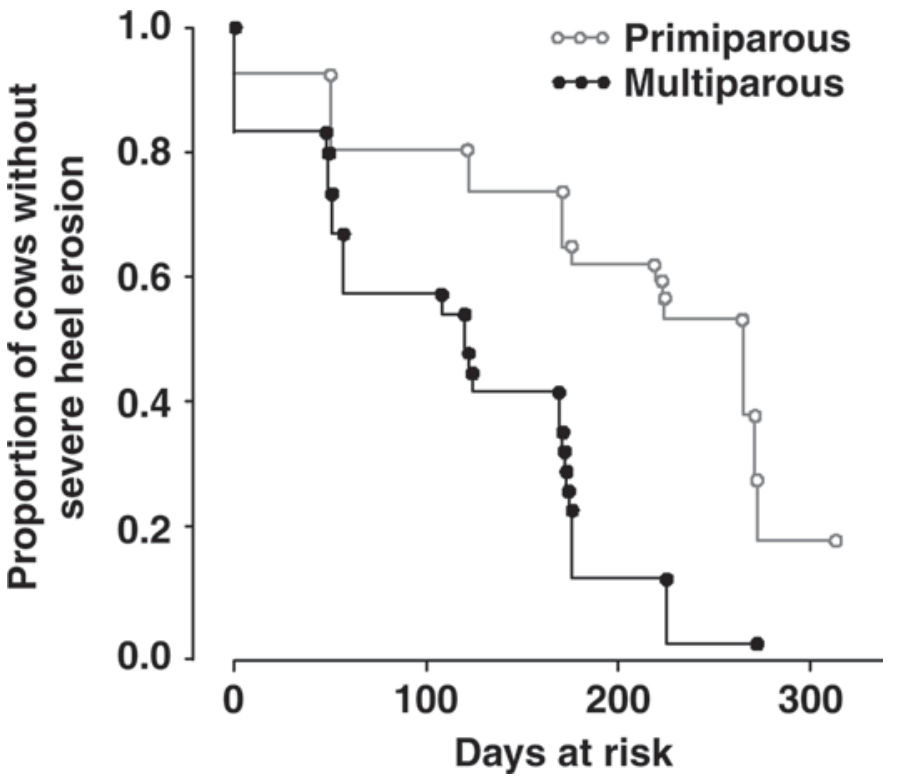

Figure 2. Survival distribution function for time to development of severe heel erosion for primiparous and multiparous cows. Days at risk are relative to the first hoof examination. Cows that presented severe heel erosion at the first examination were not considered in the analyses.

after calving, thus missing the lactation stage at which the risk of heel erosion is highest.

We found that multiparous cows had a higher risk of severe heel erosion, and the risk of severe heel erosion increased as lactation progressed for both primiparous and multiparous cows. This supports Enevoldsen et al. (1991), who found an increased risk of heel erosion in older cows and that the risk of heel erosion increased with stage of lactation. However, Offer et al. (2000) did not find a relationship between heel erosion severity and parity. Several other studies have shown that heel erosion did not improve in early or mid lactation when cows were housed indoors (Livesey et al., 1998; Webster, 2002; Olmos et al., 2009).

To our knowledge, this is the first study that assessed incidence and changes in risk over time of severe heel erosion. The results show that stage of lactation and parity are major risk factors for severe heel erosion in dairy cattle housed in freestalls. Further research is needed to understand what types of housing systems can both reduce the risk of developing heel erosion and help affected animals recover.

\section{ACKNOWLEDGMENTS}

We thank the staff and students at the University of British Columbia's Dairy Education and Research Centre (Agassiz, British Columbia, Canada). We especially thank Erin Bell, Frances Flower, and Pablo 
Nunes for their help throughout the project. L. C. Pinheiro Machado Filho was sponsored by CAPES (Coordenação de Aperfeiçoamento de Pessoal de Nivel Superior, Brazil). The Animal Welfare Program is funded by Canada's Natural Sciences and Engineering Research Council (Ottawa, Ontario, Canada) Industrial Research Chair Program with industry contributions from the Dairy Farmers of Canada (Ottawa, Ontario, Canada), Westgen Endowment Fund (Milner, British Columbia, Canada), Pfizer Animal Health (Kirkland, Quebec, Canada), BC Cattle Industry Development Fund (Kamloops, British Columbia, Canada), the BC Milk Producers (Burnaby, British Columbia, Canada), BC Dairy Foundation (Burnaby, British Columbia, Canada), BC Dairy Education and Research Association (Abbotsford, British Columbia, Canada), and Alberta Milk (Edmonton, Alberta, Canada).

\section{REFERENCES}

Bergsten, C., and A. H. Herlin. 1996. Sole haemorrhages and heel horn erosion in dairy cows: The influence of housing system in their prevalence and severity. Acta Vet. Scand. 37:395-408.

Bergsten, C., and B. Pettersson. 1992. The cleanliness of cows tied in stalls and the health of their hooves as influenced by the use of electric trainers. Prev. Vet. Med. 13:229-238.

Capion, N., S. M. Thamsborg, and C. Enevoldsen. 2009. Prevalence and severity of foot lesions in Danish Holstein heifers through first lactation. Vet. J. 182:50-58.

Cramer, G., K. D. Lissemore, C. L. Guard, K. E. Leslie, and D. F. Kelton. 2008. Herd- and cow-level prevalence of foot lesions in Ontario dairy cattle. J. Dairy Sci. 91:3888-3895.

Enevoldsen, C., Y. T. Grohn, and I. Thysen. 1991. Heel erosion and other interdigital disorders in dairy cows: Associations with season, cow characteristics, disease, and production. J. Dairy Sci. 74:1299-1309.

Esslemont, R. J., and E. J. Peeler. 1993. The scope for raising margins in dairy herds by improving fertility and health. Br. Vet. J. 149:537-547.

Frankena, K., J. G. C. J. Somers, W. G. P. Schouten, J. V. van Stek, J. H. M. Metz, E. N. Stassen, and E. A. M. Graat. 2009. The effect of digital lesions and floor type on locomotion score in Dutch dairy cows. Prev. Vet. Med. 88:150-157.

Green, L. E., V. J. Hedges, Y. H. Schukken, R. W. Blowey, and A. J. Packington. 2002. The impact of clinical lameness on the milk yield of dairy cows. J. Dairy Sci. 85:2250-2256.
Greenough, P. R., and A. D. Weaver. 1997. Lameness in Cattle. 3rd ed. W. B. Saunders, Philadelphia, PA.

Hultgren, J., and C. Bergsten. 2001. Effects of rubber-slatted flooring systems on cleanliness and foot health in tied dairy cows. Prev. Vet. Med. 52:75-89.

Livesey, C. T., T. Harrington, A. M. Johnston, S. A. May, and J. A. Metcalf. 1998. The effect of diet and housing on the development of sole haemorrhages, white line haemorrhages and heel erosions in Holstein heifers. Anim. Sci. 67:9-16.

Manske, T., J. Hultgren, and C. Bergsten. 2002a. Topical treatment of digital dermatitis associated with severe heel-horn erosion in a Swedish dairy herd. Prev. Vet. Med. 53:215-231.

Manske, T., J. Hultgren, and C. Bergsten. 2002b. Prevalence and interrelationships of hoof lesions and lameness in Swedish dairy cows. Prev. Vet. Med. 54:247-263.

NRC. 2001. Nutrient Requirement of Dairy Cattle. 7th rev. ed. National Academy Press, Washington, DC.

Offer, J. E., D. McNulty, and D. N. Logue. 2000. Observations of lameness, hoof conformation and development of lesions in dairy cattle over four lactations. Vet. Rec. 147:105-109.

Olmos, G., L. Boyle, A. Hanlon, J. Patton, J. J. Murphy, and J. F. Mee. 2009. Hoof disorders, locomotion ability and lying times of cubicle-housed compared to pasture-based dairy cows. Livest. Sci. 125:199-207.

SAS Institute. 2003. SAS User's Guide. SAS Institute Inc., Cary, NC.

Smilie, R. H., K. H. Hoblet, M. L. Eastridge, W. P. Weiss, G. L. Schnitkey, and M. L. Moeschberger. 1999. Subclinical laminitis in dairy cows: Use of severity of hoof lesions to rank and evaluate herds. Vet. Rec. 144:17-21.

Smit, H., B. Verbeek, D. J. Peterse, J. Jansen, B. T. McDaniel, and R. D. Politiek. 1986. The effects of herd characteristics on claw disorders and claw measurements in Friesians. Livest. Prod. Sci. $15: 1-9$.

Smits, M. J. C., K. Frankena, J. H. M. Metz, and J. P. T. M. Noordhuizen. 1992. Prevalence of digital disorders in zero-grazing dairy cows. Livest. Prod. Sci. 32:231-244

Sogstad, A. M., T. Fjeldaas, O. Osteras, and K. P. Forshell. 2005. Prevalence of claw lesions in Norwegian dairy cattle housed in tie stalls and free stalls. Prev. Vet. Med. 70:191-209.

Tranter, W. P., and R. S. Morris. 1991. A case study of lameness in three dairy herds. N. Z. Vet. J. 39:88-96.

Vanegas, J., M. Overton, S. L. Berry, and W. M. Sischo. 2006. Effect of rubber flooring on claw health in lactating dairy cows housed in free-stall barns. J. Dairy Sci. 89:4251-4258.

Webster, A. J. F. 2002. Effects of housing practices on the development of foot lesions in dairy heifers in early lactation. Vet. Rec. 151:9 12.

Whay, H. R., A. E. Waterman, and A. J. F. Webster. 1997. Associations between locomotion, claw lesions and nociceptive threshold in dairy heifers during the peri-partum period. Vet. J. 154:155-161. 